\title{
Unmet goals in the treatment of Acute Myocardial Infarction:
}

\section{Review [version 1; peer review: 2 approved]}

\author{
Alejandro Farah (iD1, Alejandro Barbagelata2,3 \\ ${ }^{1}$ Interventional Cardiology Department, San Bernardo Hospital, Salta, Argentina \\ 2Universidad Católica de Buenos Aires, Buenos Aires, Argentina \\ ${ }^{3}$ Department of Medicine, Duke University School of Medicine, Durham, NC, USA
}

V1 First published: 27 Jul 2017, 6(F1000 Faculty Rev):1243

https://doi.org/10.12688/f1000research.10553.1

Latest published: 27 Jul 2017, 6(F1000 Faculty Rev):1243

https://doi.org/10.12688/f1000research.10553.1
Open Peer Review

Approval Status

1

2

version 1

27 Jul 2017

Faculty Reviews are review articles written by the prestigious Members of Faculty Opinions. The articles are commissioned and peer reviewed before publication to ensure that the final, published version is comprehensive and accessible. The reviewers who approved the final version are listed with their names and affiliations.

1. Takashi Akasaka, Wakayama Medical University, Kimiidera, Japan

2. Antonio Abbate, Virginia Commonwealth University, Virginia, USA

Any comments on the article can be found at the end of the article. 
Keywords

Myocardial Infarction, Reperfusion, Reperfusion Injury, Controlled

reperfusion

Corresponding authors: Alejandro Farah (farahale@yahoo.com), Alejandro Barbagelata (n.barbagelata@duke.edu)

Competing interests: The authors declare that they have no competing interests.

Grant information: The author(s) declared that no grants were involved in supporting this work.

Copyright: $\odot 2017$ Farah A and Barbagelata A. This is an open access article distributed under the terms of the Creative Commons

Attribution License, which permits unrestricted use, distribution, and reproduction in any medium, provided the original work is properly cited.

How to cite this article: Farah A and Barbagelata A. Unmet goals in the treatment of Acute Myocardial Infarction: Review [version 1; peer review: 2 approved] F1000Research 2017, 6(F1000 Faculty Rev):1243 https://doi.org/10.12688/f1000research.10553.1

First published: 27 Jul 2017, 6(F1000 Faculty Rev):1243 https://doi.org/10.12688/f1000research.10553.1 


\section{Introduction}

Atherosclerotic cardiovascular disease is the leading cause of death around the world ${ }^{1}$. Acute myocardial infarction (AMI) is the event that causes most deaths or new cases of heart failure (HF) ${ }^{2-5}$. Early reperfusion therapy decreases the amount of myocardium damaged during an acute event and consequently mortality ${ }^{6,7}$. Primary percutaneous coronary intervention (PPCI) has become the optimal reperfusion strategy when performed in a timely manner ${ }^{8-10}$. However, there are unmet needs in the treatment of AMI, limiting the benefits that could be obtained with PPCI, since mortality and HF continue to occur in about $10 \%$ and $20 \%$ of cases each year, respectively ${ }^{2-5}$. In the current state of AMI treatment, two different stages can be recognized in which decrease of reperfusion benefits and in which the wavefront of necrosis could potentially be aborted. The first stage is the time from the onset of symptoms to reperfusion (Figure 1). The second stage occurs during reperfusion (Figure 2).

Efforts to optimize the benefit of PPCI are aimed at decreasing the time from onset of symptoms to reperfusion, reducing myocardial damage during the delay, and preventing reperfusion injury.
Time reperfusion

The greatest benefit of reperfusion is obtained within the first 2 to 3 hours of ischemia ${ }^{11,12}$. The guidelines for the treatment of AMI indicate that the time from first contact with the health team for acquisition and interpretation of electrocardiogram (ECG) must be less than 10 minutes $^{13,14}$. PPCI is chosen for reperfusion if it is done in a timely manner by a trained team within 120 minutes of the first medical contact (FMC) $)^{12,15-17}$. If the FMC occurs in a PPCI center, the accepted delay to reperfusion is 90 minutes $^{17,18}$ but preferably would be less than 60 minutes. Since most patients present to centers without PPCI capabilities, door-in to door-out time in the nonPPCI center has to be less than 30 minutes for patients transferred to a PPCI center ${ }^{12,19,20}$.

If the FMC occurs in an institution without primary angioplasty (or in emergency medical services) and the expected delay for transfer for primary angioplasty has an estimated time of longer than 120 minutes, reperfusion with thrombolytic is recommended for patients without contraindications $\mathbf{s}^{17,21,22}$. In this case, the recommended time from arrival of the patient to starting the application of thrombolytic is less than 30 minutes $^{17,23,24}$.

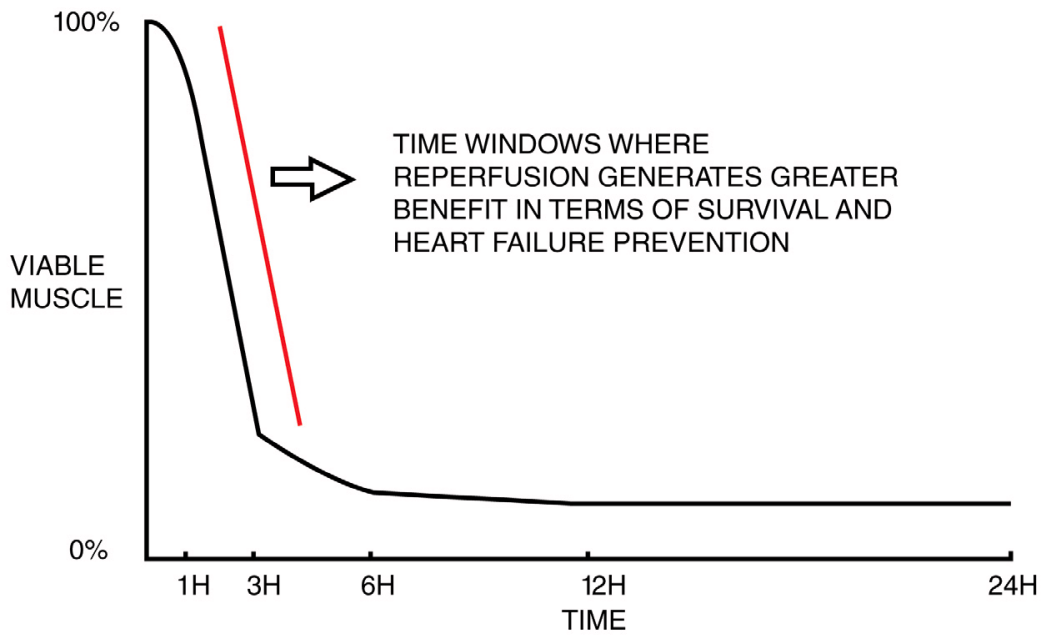

Figure 1. Relationship between time, extent of myocardial salvage, and mortality reduction.

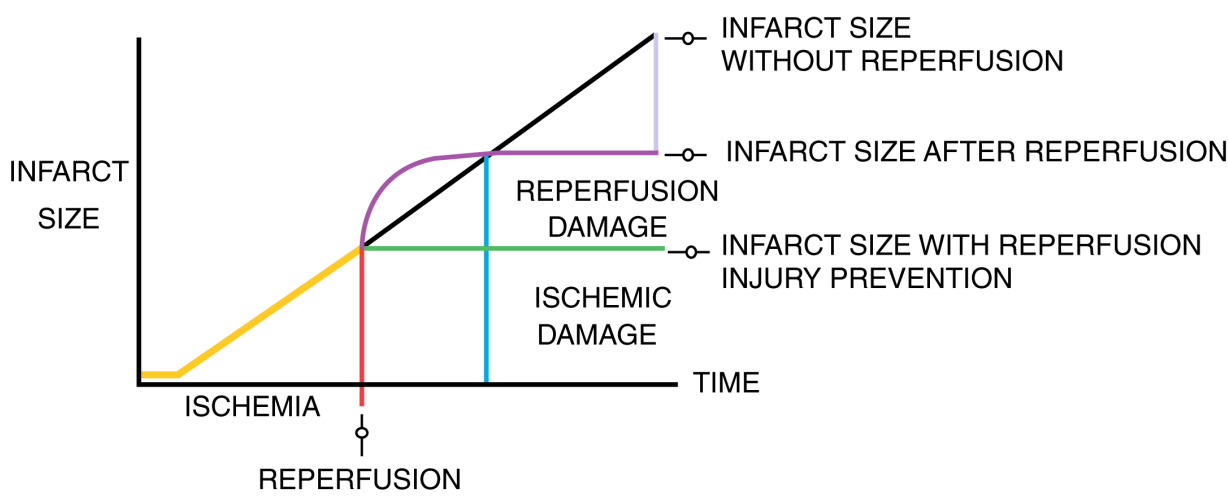

Figure 2. Ischemic injury and reperfusion injury contributions to final myocardial infarction size. 
But in the real world, the time from onset of symptoms to FMC varies widely, and usually patients wait 1.5 to 2 hours to seek medical attention, and only $66 \%$ of patients receive reperfusion within the recommendations of scientific guidelines ${ }^{25}$. The variables related to delay from onset of symptoms to the FMC are the following: female gender; older age and those younger than 40 years; previous cardiovascular disease, particularly coronary heart disease; renal failure; and walk-in hospital presentation and geographical location $^{26-28}$. The average time from onset of symptoms to FMC has not decreased in the last 10 years $^{28,29}$. An additional delay is generated when the initial ECG is performed by a general practitioner who takes an average of 23.9 minutes $^{30}$. There is a close correlation between system delay and short- and long-term mortality; 1-hour delay in the system involves mortality of $15 \%$ at 3.4 years, and a delay of 3 hours increases mortality to $28.1 \%$ in the same period $^{31}$. Factors related to system delay are transfers from remote regions, presentation in a center not trained in reperfusion therapy, transfers between centers, delay for the administration of thrombolytics, and delayed activation of the catheterization laboratory.

Strategies that could reduce the time to reperfusion are the following: education of the general population, generation of warning sign recognition ${ }^{32}$ and being initially assisted and transferred by an emergency service; as in the case of cardiac arrest, they may benefit from receiving timely $\mathrm{CPR}^{33}$. If the first $\mathrm{ECG}$ is performed during transport, it can be transmitted and interpreted by a specialist at the receiving center. This could allow the system to be activated while the patient is en route to the hospital ${ }^{34}$. This might also allow thrombolytic therapy to be administered as a pharmaco-invasive strategy in those patients with a long transport time to the catheterization laboratory. The pharmaco-therapy with aspirin, clopidogrel, unfractionated heparin, and tenecteplase and subsequent interventionism demonstrated outcomes equivalent to those of primary angioplasty but with twice the major bleeding, so it has to be selected only in those patients with expected long delays for $\mathrm{PPCI}^{35}$ and half the dose in the elderly population (Figure 3 ).

\section{Reperfusion injury}

Reperfusion therapy for AMI saves viable myocardium, but paradoxically the re-establishment of coronary blood flow also induces myocyte damage and death, limiting the full benefit of reperfusion in terms of reduction of infarct size and preservation of ventricular function ${ }^{36,37}$. Reperfusion itself can cause more damage and cell death; this process defines the phenomenon of reperfusion injury $^{36,38}$ that potentially is prevented by applying additional therapies ${ }^{39}$. Some evidence suggests that reperfusion injury may be responsible for up to $50 \%$ of the final myocardial damage during AMI $^{36}$ (Figure 4).

The time from the symptom onset, diabetes, thrombolysis in myocardial infarction flow 0 in the baseline angiography, culprit lesion located at the proximal anterior descending artery, and presentation with $\mathrm{HF}$ are related to a higher chance of reperfusion injury ${ }^{40,41}$. Elevated white blood cells, increased platelet activation (size and reactivity), high thromboxane A2 and ET1 levels, hyperglycemia with or without diabetes, and C-reactive protein before reperfusion are predictors of this phenomenon ${ }^{42-44}$. It is possible that some degree of reperfusion injury is always present, but those patients with a short time from symptom onset or with previous angina seem less susceptible ${ }^{45,46}$. There is a useful rule of thumb to

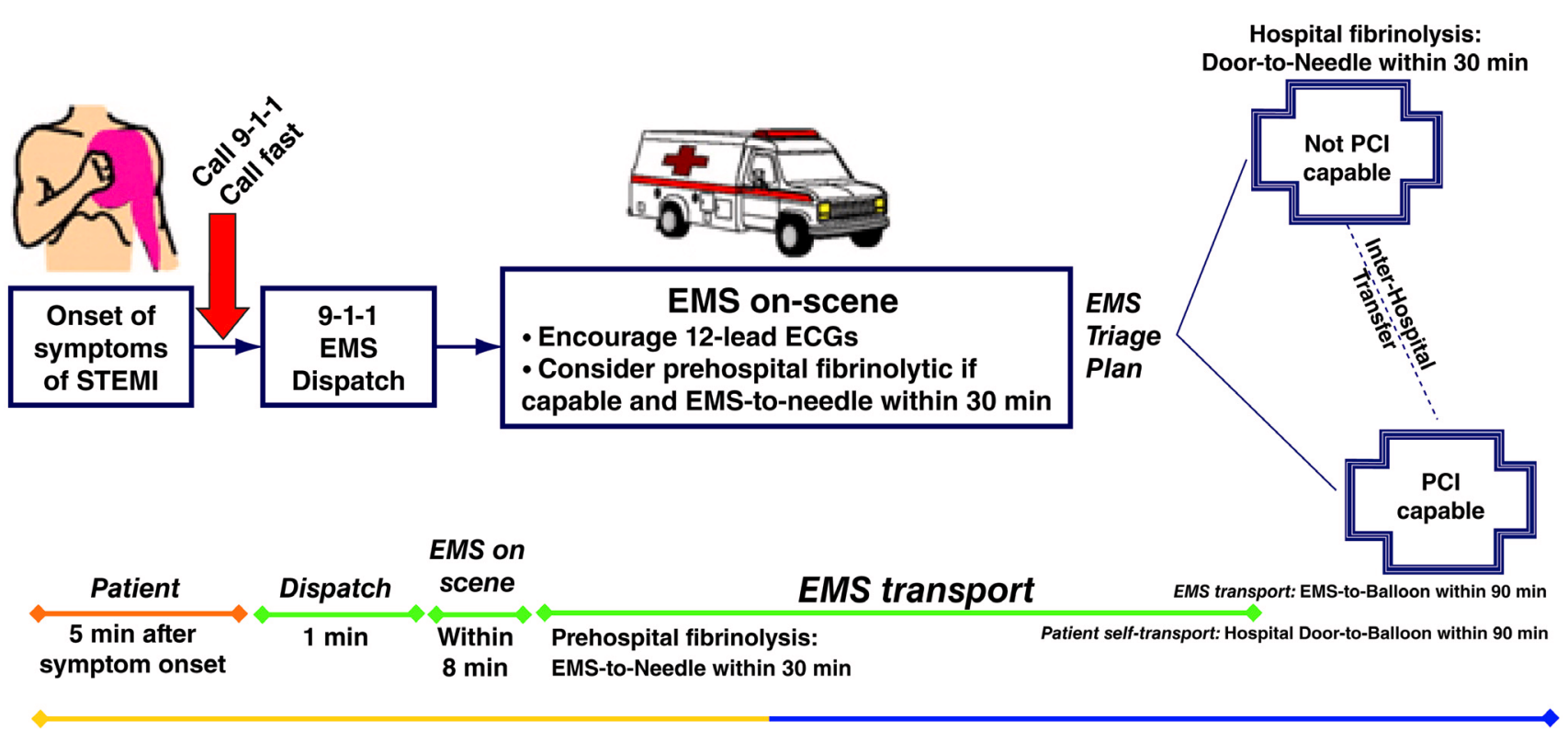

Total ischemic time: Within 120 min*

\section{${ }^{*}$ Golden Hour $=$ First 60 minutes}

Figure 3. Strategies to optimize time to reperfusion. ECG, electrocardiogram; EMS, emergency medical services; PCI, percutaneous coronary intervention; STEMI, ST elevation myocardial infarction. 

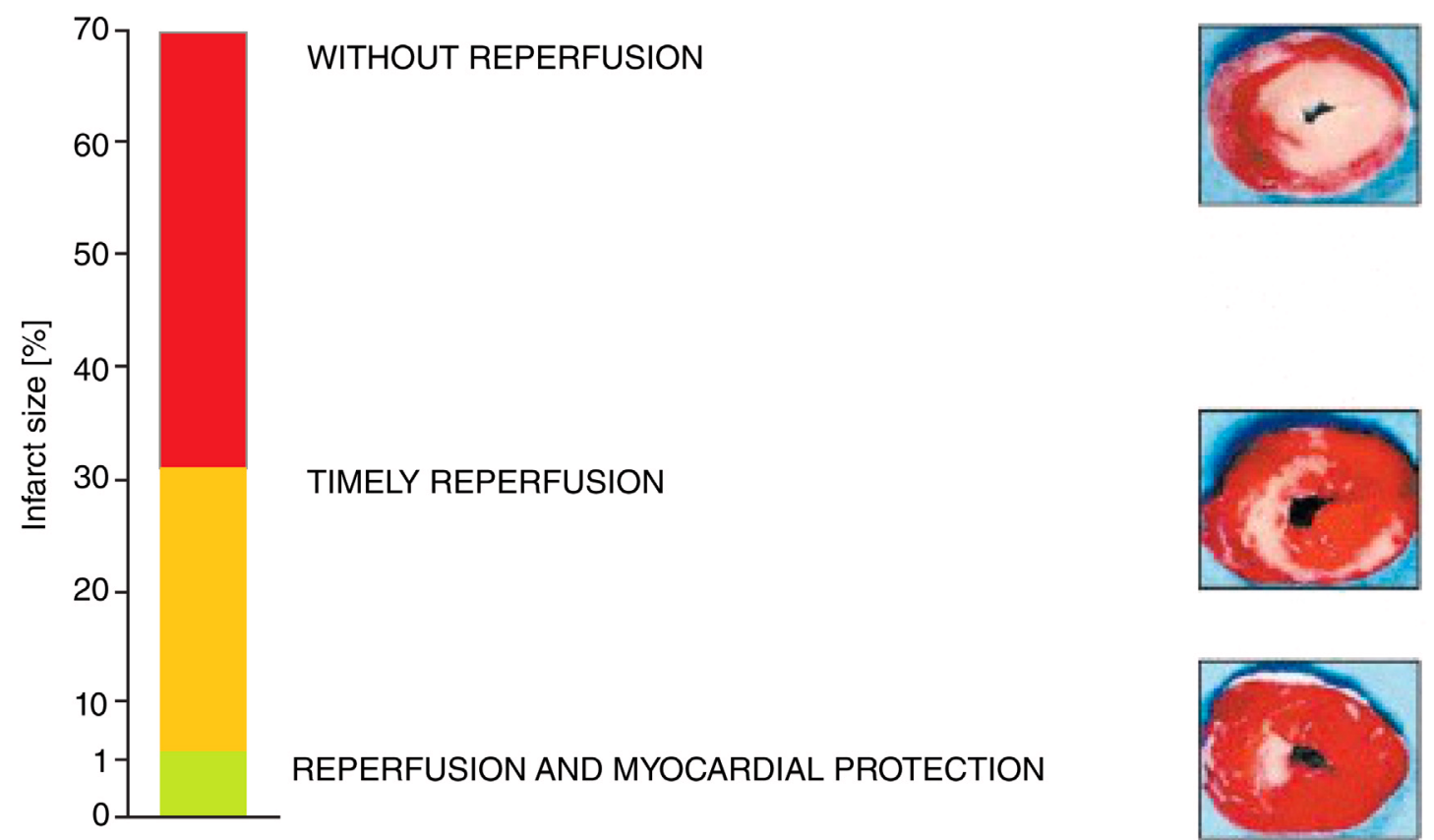

Figure 4. Potential benefits of reperfusion injury treatment.

estimate its magnitude: the greater and more intense the ischemia, the greater the reperfusion injury ${ }^{41,47-49}$. In everyday practice, the lack of ST segment resolution after achieving epicardial coronary flow is used as a marker of reperfusion failure. ST segment elevation does not decrease, mortality of AMI triples regardless of the achievement of adequate epicardial flow ${ }^{50,51}$ (Figure 5).

Diagnosis and differential diagnosis of reperfusion injury. The presence of reperfusion is a condition for reperfusion injury to exist. Clinical, electrocardiographic, and angiographic elements must be present. Clinical symptoms include increasing pain, anxiety, vegetative symptoms, and impaired hemodynamic status ${ }^{52,53}$. Electrocardiographic changes include ST segment elevation, onset of sinus tachycardia (by adrenergic discharge), malignant ventricular arrhythmias, extreme bradycardia, and electromechanical dissociation ${ }^{52-54}$. Angiographic elements include epicardial artery with signs of reperfusion and adequate antegrade flow and contrast extravasation in the microvasculature evidenced by persistent myocardial blush ${ }^{55-57}$.

Cell damage may be caused by different pathways during reperfusion (Figure 6). The main event occurring during reperfusion and trigger of reperfusion injury is the abrupt increase of oxygen content in a medium with low $\mathrm{pH}$ (acidosis tissue caused by ischemia). In this scenario, the $\mathrm{O}_{2}$ reacts with hydrogen protons to reactive oxygen species (ROS), causing damage to DNA, protein, and lipid membranes, producing myocardial cell death $^{58,59}$. In addition, ROS have pro-inflammatory effects, causing apoptosis and cell necroptosis ${ }^{60}$. At the mitochondrial level, ROS open mitochondrial permeability transition pores, making them susceptible to irreversible damage ${ }^{60}$. The damage produced by ROS at the level of the endoplasmic reticulum alters calcium dynamics, which in the context of acidotic reperfusion generates calcium influx into the sarcolemma, producing sustained hypercontraction and contraction band necrosis ${ }^{59-61}$. In addition, the influx of calcium-dependent proteases degrades structural components of the cell.

Reperfusion injury affects not only myocytes but also the microvasculature, where ROS produce direct damage of endothelial cells, causing increased permeability of the capillary wall and edema. ROS are chemotactic for neutrophils, activate complement, and trigger pro-thrombotic events ${ }^{60-63}$ (Table 1 and Table 2). Finally, microvascular occlusion by perivascular edema, accumulation of neutrophils, and local thrombosis occur.

Reperfusion injury occurs by the influx of $\mathrm{O}_{2}$-saturated blood to a myocardial tissue that is made vulnerable by metabolic changes and a local internal environment that are produced during ongoing ischemia. Reperfusion injury is a rapid and irreversible phenomenon; therefore, the therapeutic strategy should focus on reducing the vulnerability of the myocardium or modify the blood that arrives to the susceptible muscle. Any therapy administered after reperfusion will be ineffective or of limited clinical benefit.

Different approaches were tested to reduce or prevent reperfusion injury and many of them failed (Table 3$)^{64}$. Occasionally, conflicting results were found in selective therapies ${ }^{64}$. Therefore, it is difficult to establish standardized treatment guidelines. Current scientific guidelines do not include reperfusion injury as a therapeutic target. It is important to note that, until recently, reperfusion injury and no-reflow were interpreted as a single entity (Table 4) and we should differentiate them as different entities; whereas no-reflow is the failure to obtain tissue flow, reperfusion injury is actually the damage produced by achieving flow. Therefore, the way to treat no-reflow 


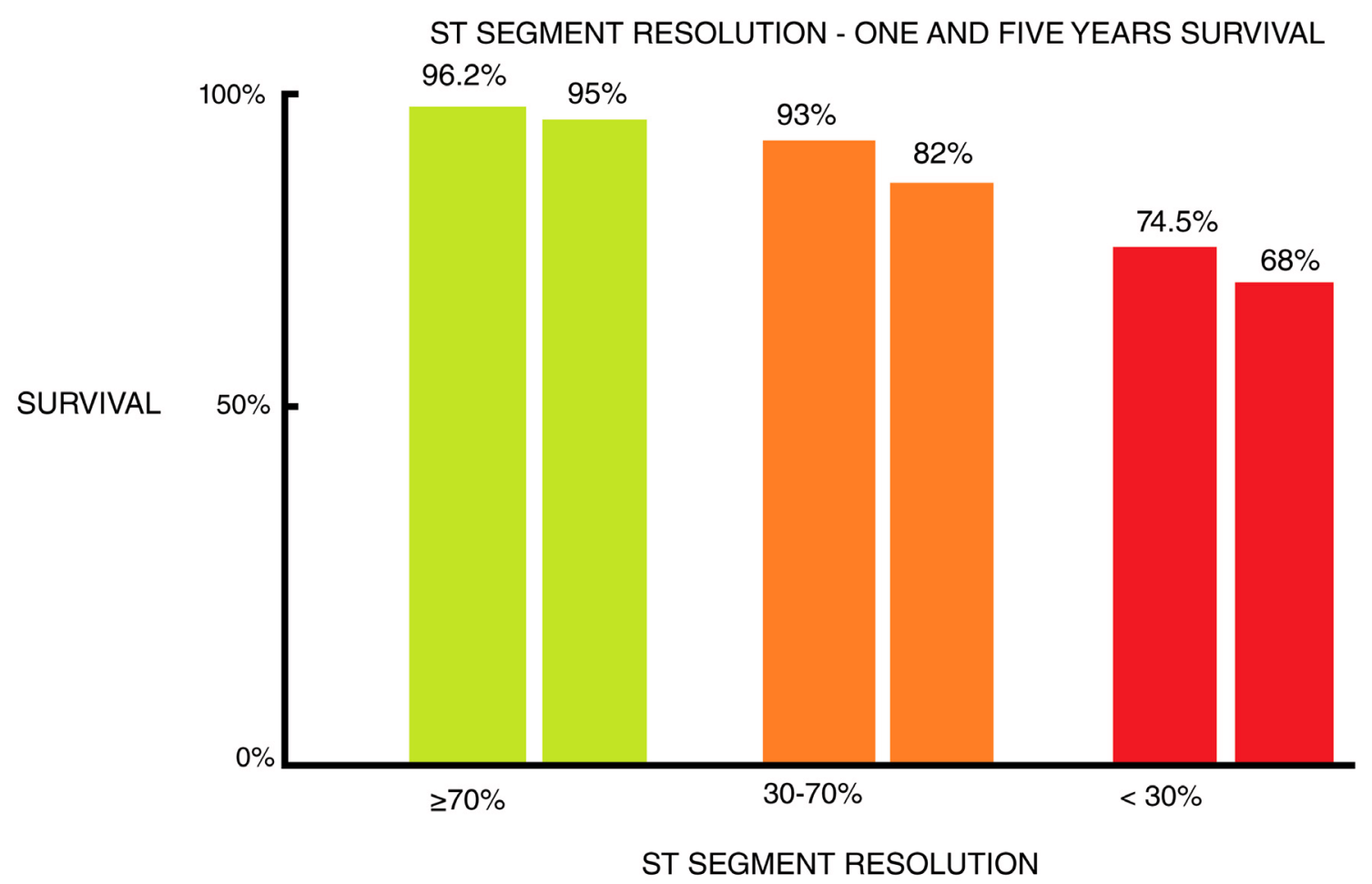

Figure 5. Relationship between lack of ST segment resolution and mortality.

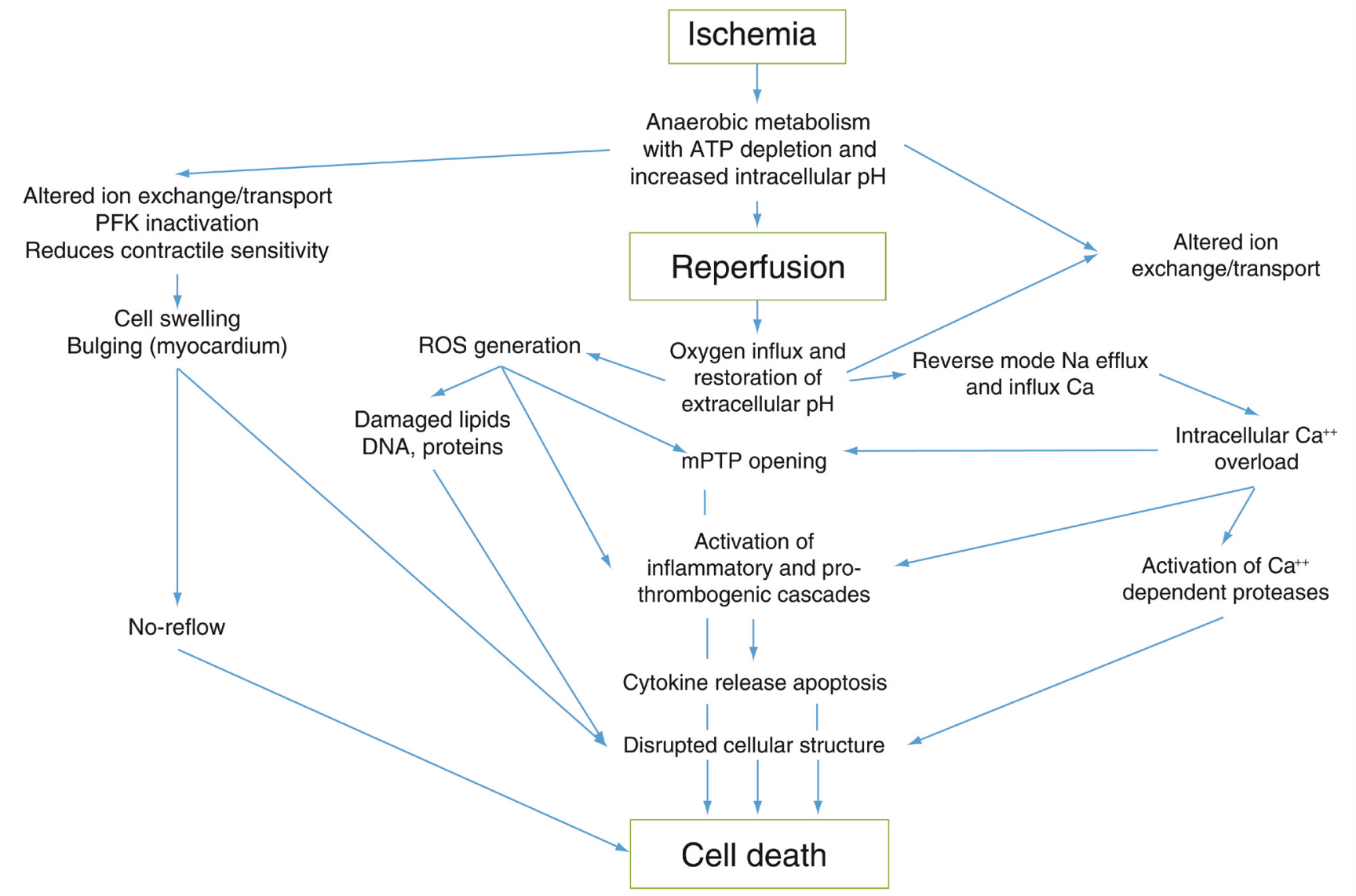

Figure 6. Physiopathologic events contributing to ischemic and reperfusion injury. PTP: membrane protein transition pore, ROS: reactive oxigen species, PFK: Phosphofructokinase. 


\section{Table 1. Reperfusion injury: physiopathogenic elements.}

Oxidative/nitrosative stress

Calcium overload

Endoplasmic reticulum stress

Mitochondrial dysfunction

Activation of apoptotic and autophagic pathways

Protein kinases

Epigenetic changes

Inflammation

Protein cleavage products and other degradation products

Table 2. Reactions that produce free radicals.

\begin{tabular}{|l|l|}
\hline Superoxide production & $\mathrm{O}_{2}+\mathrm{e}^{-}: \mathrm{O}_{2}^{-}$ \\
\hline Hydrogen peroxide production & $2 \mathrm{H}^{+} \mathrm{O}_{2}: \mathrm{H}_{2} \mathrm{O}_{2}$ \\
\hline Haber-Weiss reaction & $\mathrm{O}_{2}^{-}+\mathrm{H}_{2} \mathrm{O}_{2}: \mathrm{O}_{2}+2 \mathrm{OH}$ \\
\hline Fenton reaction & $\mathrm{Fe}^{2+}+\mathrm{H}_{2} \mathrm{O}_{2}: \mathrm{OH}+\mathrm{OH}^{-} \mathrm{Fe}^{3+}$ \\
\hline Peroxynitrite production & $\mathrm{O}_{2}^{-}+\mathrm{NO}: \mathrm{ONOO}$ \\
\hline Peroxynitrous acid production & $\mathrm{ONOO}^{-}+\mathrm{H}^{+}: \mathrm{ONOOH}$ \\
\hline Breakdown of peroxynitrous acid & $\mathrm{ONOOH}: \mathrm{OH}_{+} \mathrm{NO}_{2}$ \\
\hline $\mathrm{NO}_{2}$ and $\mathrm{CO}_{3}$ production & $\mathrm{ONOO}^{-}+\mathrm{CO}_{2}: \mathrm{NO}_{2}+\mathrm{CO}_{3}$ \\
\hline
\end{tabular}

is to obtain tissue flow, whereas in reperfusion injury the treatment objective is to protect the susceptible myocardium from reperfusion injury. Another problem for the evaluation of clinical trials is that it is difficult to detect successful treatment for no-reflow and distinguish it from success in treating reperfusion injury if ultimately the common goal is to preserve the myocardium and there is no diagnosis of any of the phenomena before therapy is applied.

Given the pathophysiological difference of both entities, it may be considered that there is no reperfusion injury if no-reflow occurs. If a treatment is useful for no-reflow, this does not imply that it is useful for reperfusion injury. For example, perhaps thromboaspiration, glycoprotein IIb IIIa inhibitors, and vasodilators such as adenosine are effective for treatment of no-reflow but this does not mean that they avoid damage caused by ROS and pro-inflammatory cytokines. Likely, in a given patient, any therapeutic option for reperfusion injury is effective if the no-reflow phenomenon is solved first, the patient is being treated for an event that will not happen. Therefore the efficacy of treatment for each phenomena should be assessed separately in clinical trials. We also have to consider the treatment of both entities as predominantly preventive; therefore, clinicians need to start treatment before the phenomenon occurs and compare their effectiveness with controls.

It is reasonable to choose, as the definition of success for trials evaluating therapies in no-reflow, the presence of myocardial blush, whereas reperfusion injury therapies should define success by ST correction in the presence of positive myocardial blush (Table 5).

Table 3. Simplified evaluation scheme treatment of reperfusion injury.

\begin{tabular}{|l|l|l|l|}
\hline $\begin{array}{l}\text { Therapeutic } \\
\text { target }\end{array}$ & Treatment & $\begin{array}{l}\text { Route of } \\
\text { administration }\end{array}$ & Result \\
\hline Indeterminate & Hypothermia & IV & - \\
\hline & Hypothermia & Peritoneal & - \\
\hline MMTP & Delcasetrib & IV before reperfusion & - \\
\hline & TR040303 & IV before reperfusion & - \\
\hline & Bendavia & IV before reperfusion & - \\
\hline $\begin{array}{l}\text { Nitric oxide } \\
\text { signaling }\end{array}$ & Ciclosporin A & IV before reperfusion & +- \\
\hline & Nitrite sodium & IV & - \\
\hline Nitrite sodium & Intracoronary & - \\
\hline $\begin{array}{l}\text { Pro-survival } \\
\text { kinase }\end{array}$ & Copertide & IV & - \\
\hline & Exenatide & IV & + \\
\hline Indeterminate & Metoprolol & IV & + \\
\hline Indeterminate & Post-conditioning & IC balloon inflations & ++- \\
\hline Indeterminate & RIC & Limb ischemia & ++++ \\
\hline & & & +++ \\
\hline
\end{tabular}

+ , one trial with positive results; -, one trial with negative results; IC, intracoronary; IV, intravascular; MMTP, mitochondrial permeability transition pore; RIC, remote ischemic conditioning. 
Table 4. Differential diagnosis with no-reflow.

\begin{tabular}{|l|l|l|}
\hline Clinic & Reperfusion injury & No-reflow \\
\hline Electrocardiography & Sudden clinical deterioration & $\begin{array}{l}\text { No changes to the state prior to } \\
\text { reperfusion }\end{array}$ \\
\hline Angiography & $\begin{array}{l}\text { ST unchanged with respect to } \\
\text { electrocardiogram prior to reperfusion }\end{array}$ \\
\hline & $\begin{array}{l}\text { Thrombolysis in myocardial infarction } \\
\text { (TIMI) 2-3 at epicardial artery }\end{array}$ & No blush or slow blush \\
\hline
\end{tabular}

Table 5. Theoretical model to evaluate success for no-reflow and reperfusion injury treatment.

\begin{tabular}{|l|l|l|l|}
\hline Treatment & Myocardial Blush & ST & $\begin{array}{l}\text { No-reflow/Reperfusion } \\
\text { injury }\end{array}$ \\
\hline & + & $\downarrow$ & Success/Success \\
\hline & + & $\uparrow$ & Success/Failure \\
\hline & - & $\uparrow$ & Failure/? \\
\hline a & $?$ & $\uparrow$ & ?/Failure \\
\hline a & $?$ & $\downarrow$ & ?/Success \\
\hline
\end{tabular}

aThe existence of the latter two possibilities in this table is explained if one can evaluate a treatment for reperfusion injury by administering it by a microcatheter, balloon over the wire, or other similar device that can administer treatment before acting on the epicardial occlusion.

Pro-inflammatory and cytotoxic phenomena (not only local but systemic), which are triggered during ischemia and reperfusion, may continue to produce myocardial damage. These mechanisms could explain why some patients with successful reperfusion continue to lose myocardium ( $\mathrm{R}$ wave of ECG) in the following reperfusion hours.

\section{Perspectives}

The development of reperfusion therapies for AMI meaningfully reduced mortality. There are possibilities to optimize their use. Health teams should continue fighting to shorten the system delay and identify the best strategy according to the context in which they operate. To this end, initiatives such as Stent for Life are expanding around the world. There are working groups that conduct research in basic science, translational research, and clinical research against reperfusion injury, such as the Hatter Cardiology Institute, which (led by Derek Yellon) is making progress in myocardial protection using remote ischemic conditioning. We are working on primary controlled reperfusion and starting a clinical assay using intracoronary dextran plus vein blood through the balloon catheter before opening the artery. See Dextran Use for Primary Angioplasty Protection in Acute Myocardial Infarction. DUPAP Trial at ClinicalTrials.gov.

We hypothesized that developing treatment protocols for "continuous myocardial protection" with different drugs, such as cyclosporine or other modulators of inflammation, administered from the time of diagnosis to the patient convalescence at the critical unit, could preserve myocardium during the delay of the system and during the early evolution of the event. To develop procedures of "controlled reperfusion" where interventional cardiologists assume treatment not only for the culprit vessel infarction but also for myocardium could reduce reperfusion injury. The newer concept of "controlled reperfusion" means deciding how to reperfuse (for example, post-conditioning with successive balloon inflations) and which adjunct compound to use during reperfusion (for example, administering to the ischemic myocardium, through dedicated catheters, prior to the opening of the artery, modified blood or enriched with drugs), preparing the myocardium for a more complete and definitive recovery. These two concepts- "continuous myocardial protection" and "controlled reperfusion"- open a wide field of research and development with potential benefits that could decrease myocardial damage and mortality.

\section{Abbreviations}

AMI, acute myocardial infarction; ECG, electrocardiogram; FMC, first medical contact; HF, heart failure; PPCI, primary percutaneous coronary intervention; ROS, reactive oxygen species.

\section{Competing interests}

The authors declare that they have no competing interests.

\section{Grant information}

The author(s) declared that no grants were involved in supporting this work. 
1. Global Projections of mortality and causes of death, 2015 and 2030 MORTALITY - WHO. On line publication. 2016.

2. Steg PG, Dabbous OH, Feldman LJ, et al:: Determinants and prognostic impact of heart failure complicating acute coronary syndromes: observations from the Global Registry of Acute Coronary Events (GRACE). Circulation. 2004; 109(4): 494-9.

PubMed Abstract | Publisher Full Text

3. Velazquez EJ, Francis GS, Armstrong PW, et al:: An international perspective on heart failure and left ventricular systolic dysfunction complicating myocardial infarction: the VALIANT registry. Eur Heart J. 2004; 25(21): 1911-9. PubMed Abstract | Publisher Full Text

4. Hellermann JP, Jacobsen SJ, Redfield MM, et al:: Heart failure after myocardial infarction: clinical presentation and survival. Eur J Heart Fail. 2005; 7(1): 119-25. PubMed Abstract | Publisher Full Text

5. Jhund PS, McMurray JJ: Heart failure after acute myocardial infarction: a lost battle in the war on heart failure? Circulation. 2008; 118(20): 2019-21. PubMed Abstract | Publisher Full Text

6. Gibson CM: NRMI and current treatment patterns for ST-elevation myocardial infarction. Am Heart J. 2004; 148(5 Suppl): S29-33. PubMed Abstract | Publisher Full Text

7. Keeley EC, Hillis LD: Primary PCI for myocardial infarction with ST-segment elevation. N Engl J Med. 2007; 356(1): 47-54. PubMed Abstract | Publisher Full Text

8. Grines $\mathrm{CL}$, Cox DA, Stone GW, et al.: Coronary angioplasty with or without stent implantation for acute myocardial infarction. Stent Primary Angioplasty in Myocardial Infarction Study Group. N Engl J Med. 1999; 341(26): 1949-56. PubMed Abstract | Publisher Full Text

9. Stone GW, Brodie BR, Griffin JJ, et al.: Prospective, multicenter study of the safety and feasibility of primary stenting in acute myocardial infarction: in-hospital and 30-day results of the PAMI stent pilot trial. Primary Angioplasty in Myocardial Infarction Stent Pilot Trial Investigators. J Am Coll Cardiol. 1998; 31(1): 23-30.

PubMed Abstract | Publisher Full Text

10. Keeley EC, Boura JA, Grines CL: Primary angioplasty versus intravenous thrombolytic therapy for acute myocardial infarction: a quantitative review of 23 randomised trials. Lancet. 2003; 361(9351): 13-20. PubMed Abstract | Publisher Full Text

11. F Gershlick AH, Banning AP, Myat A, et al.: Reperfusion therapy for STEMI: is there still a role for thrombolysis in the era of primary percutaneous coronary intervention? Lancet. 2013; 382(9892): 624-32. PubMed Abstract | Publisher Full Text | F1000 Recommendation

12. Kolh $P$, Windecker S: ESC/EACTS myocardial revascularization guidelines 2014. Eur Heart J. 2014; 35(46): 3235-6. PubMed Abstract | Publisher Full Text

13. Rokos IC, French WJ, Koenig WJ, et al.: Integration of pre-hospital electrocardiograms and ST-elevation myocardial infarction receiving cente (SRC) networks: impact on Door-to-Balloon times across 10 independent regions. JACC Cardiovasc Interv. 2009; 2(4): 339-46.

PubMed Abstract | Publisher Full Text

14. F Diercks DB, Kontos MC, Chen AY, et al.: Utilization and impact of prehospital electrocardiograms for patients with acute ST-segment elevation myocardial infarction: data from the NCDR (National Cardiovascular Data Registry) ACTION (Acute Coronary Treatment and Intervention Outcomes Network) Registry. J Am Coll Cardiol. 2009; 53(2): 161-6. PubMed Abstract | Publisher Full Text | F1000 Recommendation

15. Andersen HR, Nielsen TT, Rasmussen $\mathrm{K}$, et al.: A comparison of coronary angioplasty with fibrinolytic therapy in acute myocardial infarction. $N$ Engl $J$ Med. 2003; 349(8): 733-42. PubMed Abstract | Publisher Full Text

16. F Nielsen PH, Terkelsen CJ, Nielsen TT, et al: System delay and timing of intervention in acute myocardial infarction (from the Danish Acute Myocardial Infarction-2 [DANAMI-2] trial). Am J Cardiol. 2011; 108(6): 776-81. PubMed Abstract | Publisher Full Text | F1000 Recommendation

17. O'Gara PT, Kushner FG, Ascheim DD, et al:: 2013 ACCF/AHA guideline for the management of ST-elevation myocardial infarction: a report of the American College of Cardiology Foundation/American Heart Association Task Force on Practice Guidelines. Circulation. 2013; 127(4): e362-e425. PubMed Abstract | Publisher Full Text

18. F Sorensen JT, Terkelsen CJ, Norgaard BL, et al:: Urban and rural implementation of pre-hospital diagnosis and direct referral for primary percutaneous coronary intervention in patients with acute ST-elevation myocardial infarction. Eur Heart J. 2011; 32(4): 430-6. PubMed Abstract | Publisher Full Text | F1000 Recommendation

19. F Herrin J, Miller LE, Turkmani DF, et al:: National performance on door-in to door-out time among patients transferred for primary percutaneous coronary intervention. Arch Intern Med. 2011; 171(21): 1879-86. PubMed Abstract | Publisher Full Text | Free Full Text | F1000 Recommendation

20. F Wang TY, Nallamothu BK, Krumholz HM, et al.: Association of door-in to door-out time with reperfusion delays and outcomes among patients transferred for primary percutaneous coronary intervention. JAMA. 2011; 305(24): 2540-7.

PubMed Abstract | Publisher Full Text | F1000 Recommendation

21. Nallamothu BK, Bates ER: Percutaneous coronary intervention versus fibrinolytic therapy in acute myocardial infarction: is timing (almost) everything? Am J Cardiol. 2003; 92(7): 824-6.

PubMed Abstract | Publisher Full Text

22. Pinto DS, Kirtane AJ, Nallamothu BK, et al: Hospital delays in reperfusion for ST-elevation myocardial infarction: implications when selecting a reperfusion strategy. Circulation. 2006; 114(19): 2019-25. PubMed Abstract | Publisher Full Text

23. Boersma E, Maas AC, Deckers JW, et al.: Early thrombolytic treatment in acute myocardial infarction: reappraisal of the golden hour. Lancet. 1996; 348(9030): $771-5$

PubMed Abstract | Publisher Full Text

24. Newby LK, Rutsch WR, Califf RM, et al.: Time from symptom onset to treatment and outcomes after thrombolytic therapy. GUSTO-1 Investigators. J Am Coll Cardiol. 1996; 27(7): 1646-55.

PubMed Abstract | Publisher Full Tex

25. F Miedema MD, Newell MC, Duval S, et al.: Causes of delay and associated mortality in patients transferred with ST-segment-elevation myocardial infarction. Circulation. 2011; 124(15): 1636-44.

PubMed Abstract | Publisher Full Text | F1000 Recommendation

26. Goff DC Jr, Feldman HA, McGovern PG, et al:: Prehospital delay in patients hospitalized with heart attack symptoms in the United States: the REACT trial. Rapid Early Action for Coronary Treatment (REACT) Study Group. Am Heart J. 1999; 138(6 Pt 1): 1046-57.

PubMed Abstract | Publisher Full Text

27. Goldberg RJ, Steg PG, Sadiq I, et al:: Extent of, and factors associated with, delay to hospital presentation in patients with acute coronary disease (the GRACE registry). Am J Cardiol. 2002; 89(7): 791-6. PubMed Abstract | Publisher Full Text

28. Spencer FA, Montalescot G, Fox KA, et al:: Delay to reperfusion in patients with acute myocardial infarction presenting to acute care hospitals: an international perspective. Eur Heart J. 2010; 31(11): 1328-36. PubMed Abstract | Publisher Full Text | Free Full Text

29. Goldberg RJ, Spencer FA, Fox KA, et al.: Prehospital Delay in Patients With Acute Coronary Syndromes (from the Global Registry of Acute Coronary Events [GRACE]). Am J Cardiol. 2009; 103(5): 598-603.

PubMed Abstract | Publisher Full Text

30. F Tra J, van der Wulp I, de Bruijne MC, et al.: Exploring the treatment delay in the care of patients with ST-elevation myocardial infarction undergoing acute percutaneous coronary intervention: a cross-sectional study. BMC Health Serv Res. 2015; 15: 340

PubMed Abstract | Publisher Full Text | Free Full Text | F1000 Recommendation

31. Terkelsen CJ, Sorensen JT, Maeng M, et al: System delay and mortality among patients with STEMI treated with primary percutaneous coronary intervention. JAMA. 2010; 304(7): 763-71.

PubMed Abstract | Publisher Full Tex

32. McDermott MM, Mandapat AL, Moates A, et al.: Knowledge and attitudes regarding cardiovascular disease risk and prevention in patients with coronary or peripheral arterial disease. Arch Intern Med. 2003; 163(18): 2157-62. PubMed Abstract | Publisher Full Text

33. Becker L, Larsen MP, Eisenberg MS: Incidence of cardiac arrest during selftransport for chest pain. Ann Emerg Med. 1996; 28(6): 612-6. PubMed Abstract | Publisher Full Tex

34. Barbagelata A, Perna ER, Clemmensen $P$, et al:: Time to reperfusion in acute myocardial infarction. It is time to reduce it! J Electrocardiol. 2007; 40(3): 257-64. PubMed Abstract | Publisher Full Text

35. F Rashid MK, Guron N, Bernick J, et al: Safety and Efficacy of a Pharmacoinvasive Strategy in ST-Segment Elevation Myocardial Infarction: A Patient Population Study Comparing a Pharmacoinvasive Strategy With a Primary Percutaneous Coronary Intervention Strategy Within a Regional System. JACC Cardiovasc Interv. 2016; 9(19): 2014-20. PubMed Abstract | Publisher Full Text | F1000 Recommendation

36. Yellon DM, Hausenloy DJ: Myocardial reperfusion injury. N Engl J Med. 2007; 357(11): 1121-35 PubMed Abstract | Publisher Full Text

37. Hausenloy DJ, Yellon DM: Targeting Myocardial Reperfusion Injury--The Search Continues. N Engl J Med. 2015; 373(11): 1073-5. PubMed Abstract | Publisher Full Text

38. Braunwald E, Kloner RA: Myocardial reperfusion: a double-edged sword? J Clin Invest. 1985; 76(5): 1713-9.

PubMed Abstract | Publisher Full Text | Free Full Text

39. Piper HM, García-Dorado D, Ovize M: A fresh look at reperfusion injury. Cardiovasc Res. 1998; 38(2): 291-300. PubMed Abstract | Publisher Full Tex

40. Collet JP, Montalescot G: The acute reperfusion management of STEMI in 
patients with impaired glucose tolerance and type 2 diabetes. Diab Vasc Dis Res. 2005; 2(3): 136-43.

PubMed Abstract | Publisher Full Text

41. Iwakura K, Ito H, Kawano S, et al:: Predictive factors for development of the noreflow phenomenon in patients with reperfused anterior wall acute myocardia infarction. J Am Coll Cardiol. 2001; 38(2): 472-7.

PubMed Abstract | Publisher Full Text

42. Campo $\mathrm{G}$, Valgimigli $\mathrm{M}$, Gemmati $\mathrm{D}$, et al: Value of platelet reactivity in predicting response to treatment and clinical outcome in patients undergoing primary coronary intervention: insights into the STRATEGY Study. J Am Coll Cardiol. 2006; 48(11): 2178-85.

PubMed Abstract | Publisher Full Text

43. Niccoli G, Giubilato S, Russo E, et al:: Plasma levels of thromboxane A2 on admission are associated with no-reflow after primary percutaneous coronary intervention. Eur Heart J. 2008; 29(15): 1843-50.

PubMed Abstract | Publisher Full Text

44. Niccoli G, Lanza GA, Shaw S, et al: Endothelin-1 and acute myocardia infarction: a no-reflow mediator after successful percutaneous myocardial revascularization. Eur Heart J. 2006; 27(15): 1793-8.

PubMed Abstract | Publisher Full Text

45. Karila-Cohen D, Czitrom D, Brochet E, et al:: Decreased no-reflow in patients with anterior myocardial infarction and pre-infarction angina. Eur Heart J. 1999; 20(23): $1724-30$

PubMed Abstract | Publisher Full Text

46. Komamura K, Kitakaze M, Nishida K, et al.: Progressive decreases in coronary vein flow during reperfusion in acute myocardial infarction: clinical documentation of the no reflow phenomenon after successful thrombolysis. J Am Coll Cardiol. 1994; 24(2): 370-7.

PubMed Abstract | Publisher Full Text

47. Nallamothu BK, Bradley EH, Krumholz HM: Time to treatment in primary percutaneous coronary intervention. N Engl J Med. 2007; 357(16): 1631-8. PubMed Abstract | Publisher Full Text

48. Turschner $\mathrm{O}, \mathrm{D}$ 'hooge $\mathrm{J}$, Dommke $\mathrm{C}$, et al:: The sequential changes in myocardial thickness and thickening which occur during acute transmural infarction, infarct reperfusion and the resultant expression of reperfusion injury. Eur Heart J. 2004; 25(9): 794-803.

PubMed Abstract | Publisher Full Text

49. Uyarel $\mathrm{H}, \mathrm{Cam} \mathrm{N}$, Okmen $\mathrm{E}$, et al:: Level of Selvester QRS score is predictive of ST-segment resolution and 30-day outcomes in patients with acute myocardial infarction undergoing primary coronary intervention. Am Heart J. 2006; 151(6): 1239.e1-7.

PubMed Abstract | Publisher Full Text

50. de Lemos JA, Braunwald E: ST segment resolution as a tool for assessing the efficacy of reperfusion therapy. J Am Coll Cardiol. 2001; 38(5): 1283-94. PubMed Abstract | Publisher Full Text

51. Buller CE, Fu Y, Mahaffey KW, et al:: ST-segment recovery and outcome after primary percutaneous coronary intervention for ST-elevation myocardial infarction: insights from the Assessment of Pexelizumab in Acute Myocardial Infarction (APEX-AMI) trial. Circulation. 2008; 118(13): 1335-46. PubMed Abstract | Publisher Full Text
52. Aiello EA, Jabr RI, Cole WC: Arrhythmia and delayed recovery of cardiac action potential during reperfusion after ischemia. Role of oxygen radical-induced no-reflow phenomenon. Circ Res. 1995; 77(1): 153-62.

PubMed Abstract | Publisher Full Text

53. Ito H, Maruyama A, Iwakura $\mathrm{K}$, et al.: Clinical implications of the 'no reflow' phenomenon. A predictor of complications and left ventricular remodeling in reperfused anterior wall myocardial infarction. Circulation. 1996; 93(2): 223-8.

PubMed Abstract | Publisher Full Text

54. Rezkalla SH, Kloner RA: No-reflow phenomenon. Circulation. 2002; 105(5): 656-62.

PubMed Abstract | Publisher Full Tex

55. Perez de Prado A, Fernández-Vázquez F, Cuellas-Ramón JC, et al:: Coronary clearance frame count: a new index of microvascular perfusion. $J$ Thromb Thrombolysis. 2005; 19(2): 97-100.

PubMed Abstract | Publisher Full Tex

56. Henriques JP, Zijlstra F, van 't Hof AW, et al.: Angiographic assessment of reperfusion in acute myocardial infarction by myocardial blush grade. Circulation. 2003; 107(16): 2115-9. PubMed Abstract | Publisher Full Text

57. Appelbaum E, Kirtane AJ, Clark A, et al:: Association of TIMI myocardial perfusion grade and ST-segment resolution with cardiovascular magnetic resonance measures of microvascular obstruction and infarct size following ST-segment elevation myocardial infarction. J Thromb Thrombolysis. 2009; 27(2): 123-9.

PubMed Abstract | Publisher Full Text

58. Zweier JL, Talukder MA: The role of oxidants and free radicals in reperfusion injury. Cardiovasc Res. 2006; 70(2): 181-90. PubMed Abstract | Publisher Full Text

59. Barber AM, Maizel JV Jr: SequenceEditingAligner: a multiple sequence editor and aligner. Genet Anal Tech Appl. 1990; 7(2): 39-45. PubMed Abstract | Publisher Full Text

60. $\mathrm{F}$ Kalogeris $\mathrm{T}$, Baines $\mathrm{CP}, \mathrm{Krenz} \mathrm{M}$, et al:: Cell biology of ischemia/reperfusion injury. Int Rev Cell Mol Biol. 2012; 298: 229-317. PubMed Abstract | Publisher Full Text | Free Full Text | F1000 Recommendation

61. Hoffman JW Jr, Gilbert TB, Poston RS, et al:: Myocardial reperfusion injury: etiology, mechanisms, and therapies. J Extra Corpor Technol. 2004; 36(4): 391-411.

PubMed Abstract

62. Verma S, Fedak PW, Weisel RD, et al.: Fundamentals of reperfusion injury for the clinical cardiologist. Circulation. 2002; 105(20): 2332-6. PubMed Abstract | Publisher Full Text

63. Reffelmann T, Hale SL, Dow JS, et al: No-reflow phenomenon persists longterm after ischemia/reperfusion in the rat and predicts infarct expansion. Circulation. 2003; 108(23): 2911-7. PubMed Abstract | Publisher Full Text

64. Bulluck $\mathrm{H}$, Yellon DM, Hausenloy DJ: Reducing myocardial infarct size: challenges and future opportunities. Heart. 2016; 102(5): 341-8. PubMed Abstract | Publisher Full Text | Free Full Text 


\section{Open Peer Review}

\section{Current Peer Review Status:}

\section{Editorial Note on the Review Process}

Faculty Reviews are review articles written by the prestigious Members of Faculty Opinions. The articles are commissioned and peer reviewed before publication to ensure that the final, published version is comprehensive and accessible. The reviewers who approved the final version are listed with their names and affiliations.

\section{The reviewers who approved this article are:}

\section{Version 1}

\section{Antonio Abbate}

VCU Pauley Heart Center, Virginia Commonwealth University, Virginia, USA

Competing Interests: No competing interests were disclosed.

\section{Takashi Akasaka}

Department of Cardiovascular Medicine, Wakayama Medical University, Kimiidera, Wakayama, Japan Competing Interests: No competing interests were disclosed.

The benefits of publishing with F1000Research:

- Your article is published within days, with no editorial bias

- You can publish traditional articles, null/negative results, case reports, data notes and more

- The peer review process is transparent and collaborative

- Your article is indexed in PubMed after passing peer review

- Dedicated customer support at every stage

For pre-submission enquiries, contact research@f1000.com 